\title{
Assessing IT-business alignment in service-oriented Enterprises
}

\author{
Hsin-Lu Chang \\ Department of Information Management \\ National Chengchi University, Taipei, Taiwan, R.O.C. \\ hlchang@nccu.edu.tw \\ Hsiang-En Hsiao \\ Department of Information Management \\ National Chengchi University, Taipei, Taiwan, R.O.C. \\ kkperson@gmail.com \\ Chia-Pei Lue \\ Organizations \& Systems \& Supply Chain Division \\ PresiCarre Corporation, Taipei, Taiwan, R.O.C. \\ yanny-lue@carrefour.com
}

\begin{abstract}
Nowadays, more and more businesses transform into service-oriented enterprises in order to sustain their competitive advantage. To ensure that the underlying information technology (IT) can best support the transformation, we aim to develop an IT-business alignment framework to assess the quality of alignment in the context of service-oriented enterprises. Based upon the existing literature, we propose three components of IT-business alignment: strategic alignment, operational alignment, and social alignment. We study their various contributions to the performance of service-oriented IT projects, together with the interactions with service integration level. Our data were collected from Web questionnaires. The total dataset is derived from 300 selected companies in an on-line technology management forum. Among the returned questionnaires, 104 were found to be complete and usable; this represented a response rate of 34 percent. A Partial Least Squares (PLS) analysis is conducted and derives the following three research findings: (1) IT-business alignment plays a significant role in improving the performance of service-oriented IT; (2) the service integration level is an important performance moderator for strategic and operational alignment; (3) the service integration level is an important contributor to social alignment.
\end{abstract}

Keywords: Customer service systems, IT-business alignment, Service-oriented enterprise, Service integration. 


\section{Introduction}

Nowadays, Information Technology (IT)Business alignment plays an important role in any company. When IT aligns with business operations and strategies, IT can anticipate future business requirements and map out a trajectory to meet upcoming needs (Huang and $\mathrm{Hu}, 2007)$. Aligning IT with business strategy, however, is not an easy task. A survey by CFO Magazine in November 2003 suggested that 48 percent of Chief Financial Officers (CFOs) reported poor alignment between IT and business needs. Huang and $\mathrm{Hu}$ (2007) have pointed out that the effectiveness of IT goes well beyond software and hardware; even the best IT cannot work efficaciously for a company unless it is properly used in the right context at the appropriate time. Similarly, Luftman (2000) has stated that IT-business alignment depends on a harmony between business strategy, IT strategy, organizational structure and processes, as well as IT infrastructure and processes. Many companies, therefore, rank IT-Business alignment among the top ten of their perennial business IT issues (Luftman, 2003). There is also emergent evidence that IT and business alignment do have an impact on organizational performance (Chan and Reich, 2007; Chan et al., 2006; Khaiata and Zualkernan, 2009). Moreover, the need to identify appropriate types of IT alignment for achieving organizational goals has been recognized by alignment researchers and IT professionals (Weiss et al., 2006).

Many researchers and practitioners agree that the challenges are even greater when more and more companies focus on IT initiatives to support on-demand business (IBM Summit, 2004), or so-called service-oriented enterprise (SOE) activities to respond to new business dynamics, changing customer preferences, and disruptive technological shifts (Gosain et al., 2005). According to the IBM Summit (2004), SOE is a new organizational structure to support flexibility, innovation, and fast go-to-market activities. To achieve these goals, the integration between IT and business processes needs to achieve to a new level of success. The underlying IT should transform from simply replacing human involvement to a stonger level of integration. IT alignment should be considered at multiple levels, including processes, strategies, and workforce issues.

For these SOE, IT-business alignment becomes an important research issue, which is seldom discussed in the past literature. This study aims to develop a framework to assess IT-business alignment in the context of service orientation. Such a framework will be helpful for project managers in making decisions when they are supervising serviceoriented IT projects, or for Chief Executive Officers (CEOs) and top managers who need to transform their businesses into SOEs. Important questions that need to be addressed include the following:

(1) How can companies assess IT-business alignment in the context of service orientation?

(2) How can companies manage IT-business alignment to enhance the performance of service-oriented IT projects?

\section{Literature Review}

\section{IT-Business Alignment}

The term "IT alignment" is generally defined in reference to the alignment of an organization's IT resources with the objectives of its business unit (Moody, 2003). There are three major goals for research into IT-business alignment. The first identifies the requirements and strategies for achieving the alignment. Earl, Rockart, and Ross (1996) consider that IT management must be knowledgeable about the strategic and tactical thinking of senior managers to ensure that investments in IT are targeted towards strategic priorities. It is also crucial that the importance of ITbusiness alignment is recognized by all members in the company. Similarly, Reich and Benbasat (2000) have argued that a high level of shared domain knowledge has a positive impact on IT-business alignment. Weiss, Thorogood, and Clark (2006) insist that there are no quick fixes or easy solutions to ITbusiness alignment. Enterprises must enhance the three constructions of technology resources, business enablers, and strategic 
weapons before achieving IT-business alignment.

A second approach identifies the components of alignment that are required in enterprises. Chan (2002) proposes two different types of alignment: strategic alignment and structural alignment. Strategic alignment focuses on the fit between the priorities and activities of the IS function and those of the business unit. Structural alignment examines the degree of structural fit between IS and the business, specifically in the areas of IS decision-making rights, reporting relationships, (de) centralization of IS services and infrastructure, and the deployment of IS personnel. The research finds that IS strategic alignment is often more important than formal IS structural alignment. The author also emphasizes the importance of IS structure flexibility.

The third identifies methods, techniques, and tools that can enhance IT-business alignment. For example, Huang and Hu (2007) suggest that the balanced scorecard is an appropriate tool to ensure IT alignment with the entire company's strategic programs. They also point out numerous organizational, cultural, and political barriers that may inhibit alignment. Peak and Guynes (2003) recommend an IT alignment planning process to connect strategic and tactical business goals with IT strategies, resources, systems, and services.

In summary, alignment is not just a process, but a mindset of how IT can work for, and with, business all the time; in other words, it is a basic principle of the interaction between IT and business. In this context, alignment can aid stakeholders in developing a clearer understanding of the goals and objectives of a project at the outset and maximize the potential return on IT investment (Huang and $\mathrm{Hu}$, 2007).

\section{SOE and the underlying IT}

Service orientation is defined as a design paradigm that specifies the creation of automation logic in the form of services (Chang and Lue, 2009). Service-oriented architecture (SOA) is often viewed as an enabler of service orientation and is an architectural style based on which existing or new functionalities are grouped into atomic services. These services communicate with each other by passing data from one service to another, or by coordinating an activity between one or more services. Other researchers have discussed similar concepts of "service orientation," such as customer orientation, market orientation, and on-demand (e.g., Narver and Slater, 1990; Slater and Narver, 1998; Cherbakov et al., 2005). IBM consolidated these concepts and proposed the "On-Demand Business Architecture" in 2004 (IBM Summit, 2004). Building upon this architecture, SOE can be explained using the four components of service science disciplines as Figure 1 shows. A detailed discussion follows.

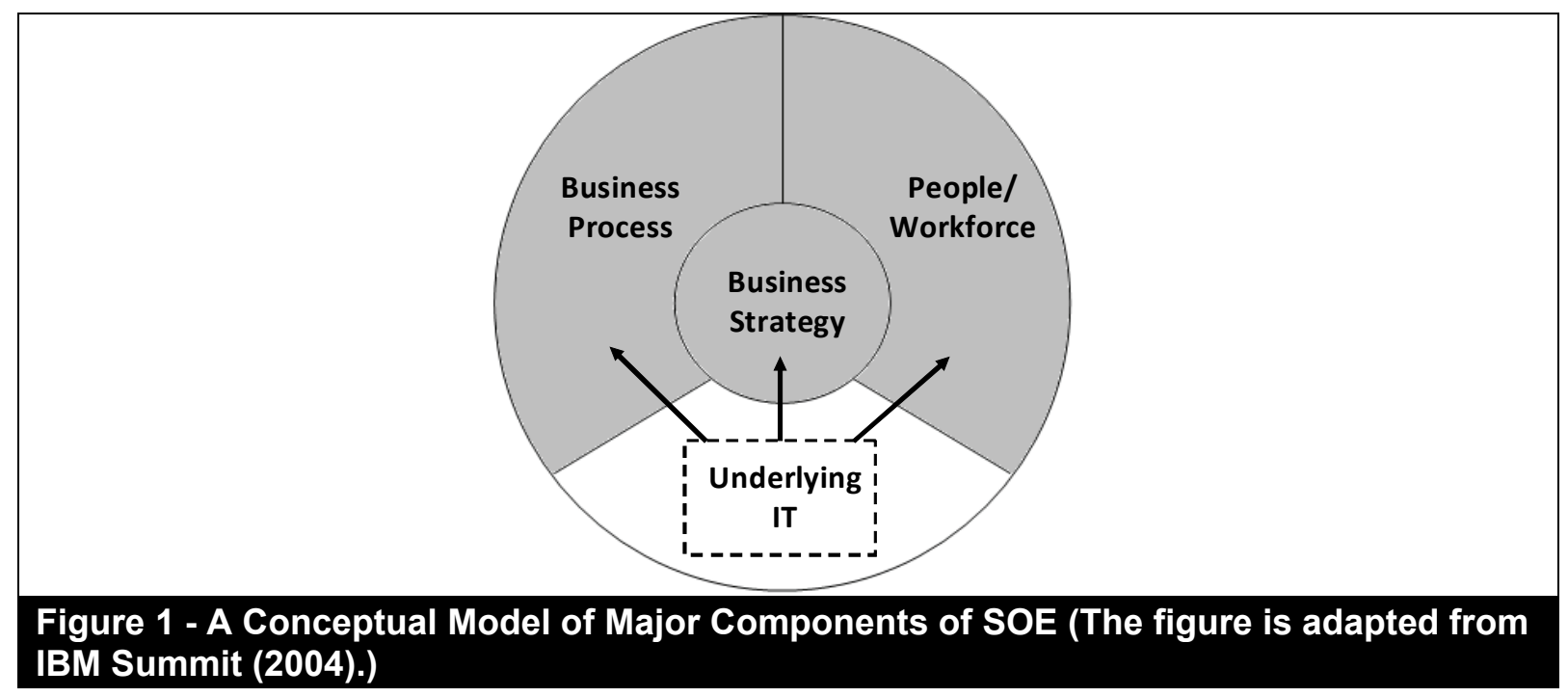


Assessing IT-business alignment in service-oriented enterprises / Chang et al.

\section{Business Components in SOE}

\section{Contexts}

\section{Business Strategy}

Before becoming an SOE, the focus of business strategy is on production push, which emphasizes on efficiency. Companies provide customer benefits and values by creating strong brand images. Slater and Narver (1998) describe such a "customer-led" strategy as a short-term philosophy in which organizations respond to customers' expressed desires. By contrast, the product strategy of SOE focuses on customer pull, which represents a long-term commitment to understanding customers' needs - both expressed and latent - and to developing innovative solutions that produce superior customer value (Slater and Narver, 1998). Customers, both internal and external, are viewed as potentially valuable sources of new offerings, ideas and opportunities, and senior managers are always willing to commit resources to exploring new service/product development projects (Menor and Roth, 2007). In addition, the supply chain organization is characterized by frequent 'partnering,' which enables firms to maintain their customer-pull strategies by continually orchestrating new sources of value creation (Gosain et al., 2005).

\section{Business Process}

In traditional enterprises, process flow is often sequential. Value creation is cumulative and based on the value chain, and therefore, the composition of services is limited (Cherbakov et al., 2005). Since process design is a static and sequential flow with decision points in predefined sequences, modeling is focused on decomposition (Cherbakov et al., 2005). SOE, in contrast, contains modularized, standardized, and net-like process flows, as well as real-time and dynamic process designs (Menor and Roth, 2007). Modularization promotes reusability (Bieberstein et al., 2005). The net-like process flow proceeds through the composition and enhancement (and often parallel execution) of existing services provided by participants in the business ecosystem (Cherbakov et al., 2005). The dynamic design is based on the execution results of the sub-processes and on near real-time dynamic orchestration (Cherbakov et al., 2005).

\section{Workforce}

The workforce in traditional businesses is hierarchically arranged (i.e., a hierarchical organization structure) (Cherbakov et al., 2005). When companies transform into SOEs, they require certain specific structural elements in their workforce. The organizational structure is horizontal and network-like, and the glue that holds the organization together is a commitment to innovation and new service or product development (Cherbakov et al., 2005; Menor and Roth, 2007). Schneider et al. (1998) have discussed the "service climate" as the key concept that underlies the structure of the SOE. The service climate is defined as employee perceptions of the practices, procedures, and behaviors that are expected, supported, and rewarded with regard to customer service and customer service quality. It is critical to specify an executive as the owner for each logically connected set of services. The owner should possess both market learning skills and market response behaviors, and his responsibility should be aligned with general enterprise governance (Slater and Narver, 1999; Bieberstein et al., 2005). We summarize our discussion in Table 1.

\section{Underlying IT Paradigms in SOE Contexts}

Based on the discussion above, investment in underlying service-oriented IT should focus on the integration of IT and business processes to promote the availability of data for decision makings. Moreover, these projects need to consider developments in connectivity, automation, and technology integration to create extensible enterprises and dynamically reconfigured business relationships in response to market changes and new business relationships (Gosain et al., 2005). It is expected that these investments will have a profound influence on those who work for such companies and the way their work will be structured. Human capital mana- 


\begin{tabular}{|c|c|c|}
\hline & Traditional Enterprise & Service-Oriented Enterprise \\
\hline Business strategy & $\begin{array}{ll}\text { - } & \text { production push } \\
\text { efficiency } \\
\text { focusing on creating strong } \\
\text { brand images } \\
\text { short-term customer-led } \\
\text { strategy }\end{array}$ & $\begin{array}{l}\text { customer pull (on demand) } \\
\text { market-oriented } \\
\text { long-term commitment to understanding cus- } \\
\text { tomer needs } \\
\text { agility, responsiveness, flexibility, and market } \\
\text { acuity }\end{array}$ \\
\hline Business process & $\begin{array}{ll} & \text { sequential process flow } \\
\text { static process design }\end{array}$ & $\begin{array}{l}\text { - } \quad \text { modularized, standardized, net-like process flow } \\
\text { real-time, dynamic process design }\end{array}$ \\
\hline People/Workforce & $\begin{array}{ll}\text { - } & \text { hierarchical organization } \\
\text { structure } \\
\text { functional managers as- } \\
\text { signed to each business unit } \\
\text { emphasis on efficiency and } \\
\text { productivity }\end{array}$ & $\begin{array}{ll}\text { - } & \text { horizontal and network-like based on service } \\
\text { - } & \text { consumer and service provider relationship } \\
\text { - } & \begin{array}{l}\text { emphase owner assigned to each service category market learning skills and market } \\
\text { response behaviors }\end{array} \\
\text { - } \quad \text { the development of a service climate }\end{array}$ \\
\hline
\end{tabular}

gement and optimization therefore also becomes a critical issue when investing in service-oriented IT (Schneider et al., 1998; Cherbakov et al., 2005; Menor and Roth, 2007).

IBM has proposed the Service Integration Maturity Model (SIMM) (IBM Global Service 2005), to assess the levels of maturity of service-oriented systems. The seven levels are explained below.

Level 1: Data Integration. The organization starts from proprietary and ad-hoc integration, rendering the architecture brittle in the face of change.

Level 2: Application Integration. The organization moves toward some form of EAI (Enterprise Application Integration), albeit with proprietary connections and integration points.

Level 3: Functional Integration. The organization componentizes and modularizes major or critical parts of its application portfolio, exposing functionality in a more modular fashion. The integration between components is achieved through the interfaces and contracts between them.

Level 4: Process Integration. The organization embarks on the early phases of SOA by defining and exposing services for consumption internally or externally via business partners.

Level 5: Supply-Chain Integration. The organization extends its influence into the value chain and service eco-system. Services form a contract among suppliers, consumers, and brokers who can build their own eco-systems for on-demand interaction.

Level 6: Virtual Infrastructure. The organization now creates a virtual infrastructure to run applications after decoupling the application, its services, components, and flows. The infrastructure externalizes its monitoring, management, and events framework (common event infrastructure).

Level 7: Eco-System Integration. The organization now has dynamically re-configurable software architecture. It can compose services at run-time using externalized policy descriptions, management, and monitoring.

Based on our definition of service orientation, service-oriented IT projects that are below Level 4 are defined as weakly integrated projects in this study; those that are at Level 4 or higher are strongly integrated. We treat enterprises with strongly-matured service integration as those that have great potential to transform into SOE.

\section{IT-Business Alignment in SOE}

Figure 1 highlights three focus areas of ITbusiness alignment in SOE: (1) strategic focus, (2) process focus, and (3) workforce focus. We discuss each in detail in the following paragraphs.

Companies' strategic focus areas have changed from short-term" customer-led" to 


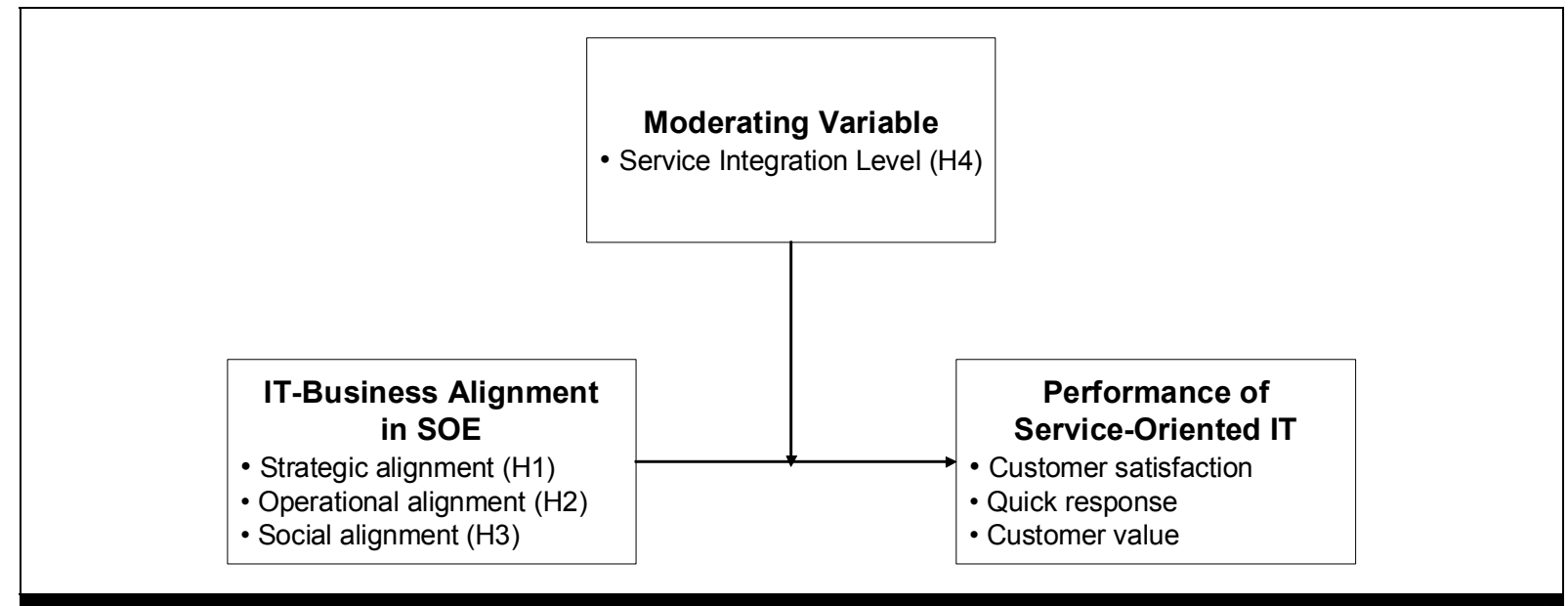

Figure 2 - Research Framework

long-term "market-oriented" (Slater and Narv er, 1998). To align with such strategic changes, IT development should enhance the agility, responsiveness, flexibilities, and market acuity of firms and enable them to acquire and evaluate market information in a systematic and anticipatory manner (Slater and Narver, 1998; Menor and Roth, 2007). The role of IT infrastructure in responding to and shaping business options with agility is recognized as being critical (Gosain et al., 2005).

The processes in SOE contexts are modularized, standardized, net-like, and incorporates real-time and dynamic process design. To align with these new types of business processes, IT projects should emphasize modularization and standardization as well. Internet technology standards are useful in providing templates for projects to create standardized, readily accessible services that are easily consumable by other clients or service applications (Bieberstein et al., 2005). There are also a number of industrial and IT vendor-driven efforts to standardize business processes and data exchanges between enterprises, which are expected to yield network externality benefits in easing partnering across enterprises and in dealing with offering changes in response to customer needs (Gosain et al., 2005).

Lastly, the structure of the workforce is transformed from a hierarchical arrangement to a horizontal, network-like structure based on service consumer and service provider relationships (Crawford et al., 2005). How to develop a service climate within a work force becomes an important issue for SOEs. To align with such a service climate, IT needs to support customer service representatives in handling different situations that are likely to arise in the customer service function. It also needs to facilitate a working environment that encourages open communication and teamwork between IT units and customer service units to provide qualitative customer service (Schneider et al., 1998).

\section{Development of research frame- work}

Our research framework is shown in Figure 2. We propose that IT-Business alignment in SOEs should focus on the integration of three components in the service science discipline: strategy, process, and workforce. Three types of IT-Business alignment are therefore examined in our research model: strategic alignment, operational alignment, and social alignment, which capture the strategic focus, process focus, and workforce focus areas of the service science discipline, respectively. The performance of service-oriented IT is the dependent variable with regard to improved customer service quality due to IT implementation (Schneider et al., 1998). Since there are various service-oriented ITs, each relating with different level of service integration, companies' efforts to leverage IT-business 
alingment to support these ITs should be vary with their embeded service integration level, and thus the effect of the service integration level on the relationship between alignment and performance is explored as the moderating variable. Relevant hypotheses are described in detail in the following sections.

\section{Strategic alignment}

Strategic alignment has been defined by TalIon and Kraemer (1999) as the extent to which the IS strategy supports and is supported by, the business strategy. Similarly, Oh and Pinsonneault (2007) consider that strategic alignment is the degree to which the priorities, goals, and objectives of the IS strategy are aligned with the priorities, goals, and objectives of the firm's business strategy. Avison et al. (2004) have summarized five definitions of strategic alignment: fit, integration, bridge, harmony, and fusion. In this paper, we adopt the concept of strategic fit between IT infrastructure and business strategy and define strategic alignment in the context of SOEs as the degree to which the underlying IT infrastructure can support corporate customer-pull service strategies. Since strategic alignment implies that any IT investment is largely driven by the overall business service strategy (Menor and Roth, 2007), we expect that IT solutions with high strategic alignment can support the design of product and services better, thereby being better able to meet specfic customer needs. Furthermore, Peak and Guynes (2003) indicate that IT solutions with high strategic alignment may be able to deliver more qualitative information to support the company's market learning and market response behaviors, thereby achieving better quality for customer service. The hypothesis is as follows:

Hypothesis 1: There is a positive relationship between strategic alignment and the performance of service-oriented IT.

\section{Operational alignment}

The literature has recognized the importance of IT alignment to business operations. Chan (2002) has suggested that IT alignment should consider the integration of the IS func- tion with the business unit structure. Moody (2003) has defined IT alignment as the alignment of an organization's IT resources with the objectives of its business unit. Weiss et al. (2006) posit that IT alignment requires the integration and coordination of IT and business resources within organizational units. Based on the above literature, we define operational alignment in the context of the SOE as the degree to which the underlying IT infrastructure can satisfy the information and process needs of service orientation in terms of modularization and standardization. Since IT with operational alignment is expected to be more modularized and standardized, it can support the composition of services better and deliver timely customer services in response to customer needs (Rockart et al., 1996; Bieberstein et al., 2005). The hypothesis is as follows:

Hypothesis 2: There is a positive relationship between operational alignment and the performance of service-oriented IT.

\section{Social alignment}

Reich and Benbasat (2000) have suggested that IT alignment should capture a social dimension in which business and IT executives share a common vision of the ways in which IT can contribute to the success of the business unit. They define the social dimension of ailgnment as "the state in which business and IT executives within an organizational unit understand and are committed to the business and IT mlssion, obJectives, and plans." Following this reasoning, Huang and $\mathrm{Hu}$ (2007) propose institutionalized culture of alignment as one of four key elements of ITbusiness alignment and argue that "management must create and maintain a system of effective communication channels between IT managers and business executives." According to previous studies, we define social alignment in the context of SOEs as the degree to which a common service climate is shared between IT and the business units. While social alignment facilitates open communication and teamwork and encourages staff to freely exchange information and knowledge (Schneider et al. 1998), we can 
Assessing IT-business alignment in service-oriented enterprises / Chang et al.

expect that IT managers have better knowledge about how IT functions can help customer service representatives to gauge customer needs. Thus, they are able to develop the systems that are needed to deliver higher customer value and provide better service. The hypothesis is as follows:

Hypothesis 3: There is a positive relationship between social alignment and the performance of service-oriented IT.

\section{Service integration level}

In this paper, service integration level is defined as the extent to which various business functions are automated and integrated in a service-oriented architecture (SOA). According to IBM Global Service (2005), service integration is a gradual process, staring from project-based application integration to enterprise-wide process and organizational transformation. IT professionals often view it as an IT capability that leads to SOE.

The impact of IT capability on IT-business alignment and IT performance has been discussed in the literature (Broadbent and Weill, 1997; Luftman et al., 1999; Chung et al., 2003; Shpilberg et al., 2007). Researchers conclude that underperforming IT results not just from misalignment, but from inadequate IT capabilities (Shpilberg et al., 2007). Companies with effective IT capabilities are able to implement IT applications that are required to support current and future business objectives, promoting the competitive positioning of business initiatives (Broadbent and Weill, 1997). However, inadequate IT capabilities can make system enhancements and infrastructure improvements aimed for new business' needs difficult to implement, leaving significant potential system benefits untapped (Luftman et al., 1999).

When companies move toward service integration, they can decouple IT applications into discrete services and form new applications by selecting required services and assembling them into new hybrid services for different purposes and requirements. IT implementation then becomes faster and more flexible, needs fewer resources, and is inte- roperable across different platforms. In the case of high levels of service integration, we expect that IT-business alignment will be more strongly associated with IT performance because a strong service integration allows companies to accelerate the delivery of IT projects through consolidation and the reuse of existing IT assets. As a result, companies can build or modify IT applications quickly and easily to fulfill the changing customer needs, reinforcing the effect of IT-business alignment in SOEs. We propose that:

Hypothesis 4: There is an interaction effect of service integration level on the relationship between IT-business alignment and the performance of service-oriented IT.

\section{Research methodology}

\section{Sample and data collection}

To test our research model, a questionnaire was designed to collect data on each of the varaibles in the model. We conducted a general survey across companies that implemented a customer service system using SOA design principles. According to SIMM, these companies were on the roadmap of transforming their organization toward more mature levels of service integration. For the companies with higher levels of service integration, their business can be customized to suit the specific needs of customers, which implies business institutionalization, including enterprise-wide process and organizational transformation. Therefore, these companies provide appropriate data for the study because they are on the transformation path of SOE.

Companies were selected from an on-line technology management forum. In 2008, the forum had 300 members, which constitute our potential respondents. With the forum's administrator's help, an on-line survey form and its website address were sent by email to these members. In the email, we defined the eligible respondents would be those who were knowledgeable about the customer service system in their companies and started to improve their system by using service orien- 


\begin{tabular}{|c|c|c|c|c|c|c|c|}
\hline \multirow{2}{*}{$\begin{array}{l}\text { Number of } \\
\text { employees }\end{array}$} & $<=5$ & $6 \sim 20$ & $21 \sim 50$ & $51 \sim 200$ & $201 \sim 500$ & $501 \sim 1000$ & $>=1000$ \\
\hline & $5 \%$ & $14 \%$ & $9 \%$ & $25 \%$ & $8 \%$ & $13 \%$ & $26 \%$ \\
\hline \multirow{2}{*}{$\begin{array}{c}\text { Company capital } \\
\text { (ten million NT } \\
\text { dollars) }\end{array}$} & $<=2$ & $2 \sim 10$ & $10 \sim 100$ & $101 \sim 500$ & $501 \sim 2000$ & $>=2000$ & \\
\hline & $22 \%$ & $26 \%$ & $24 \%$ & $8 \%$ & $5 \%$ & $15 \%$ & \\
\hline \multirow{2}{*}{$\begin{array}{c}\text { Company annual } \\
\text { sales (ten million } \\
\text { NT dollars) }\end{array}$} & $<=0.5$ & $0.5 \sim 2$ & $2 \sim 10$ & $10 \sim 50$ & $50 \sim 500$ & $>=50$ & \\
\hline & $10 \%$ & $21 \%$ & $23 \%$ & $13 \%$ & $16 \%$ & $17 \%$ & \\
\hline \multicolumn{8}{|c|}{ Industry group } \\
\hline \multicolumn{5}{|c|}{$\begin{array}{l}\text { Electronic equipment } \\
\text { Computer and peripherals } \\
\text { Information and communication } \\
\text { Machinery and equipment } \\
\text { Other manufacturing } \\
\text { Professional, scientific and technical activities } \\
\text { Retail trade } \\
\text { Others }\end{array}$} & \multicolumn{3}{|l|}{$\begin{array}{l}8.4 \% \\
39.6 \% \\
15.6 \% \\
4.1 \% \\
8.3 \% \\
11.5 \% \\
4.2 \% \\
8.3 \%\end{array}$} \\
\hline
\end{tabular}

tation. We also assured that all participants would receive a cash gift, each NTD\$200 in value. We received a total of 109 replies. Among them, 5 respondents were from the same companies; the remaining 104 respondents provided usable data. Table 2 lists profiles of the respondent companies. The industrial categorization of respondent firms is based on ISIC classes (International Standard Industrial Classification).

\section{Measurement Development}

We first conducted a series of in-depth interviews with three chief information officers (ClOs) who had significant experience in service-oriented IT projects. The survey questionnaire was then revised with their help. The performance of service-oriented IT was measured using three items to capture the expected goals of customer service systems, including increased customer satisfaction, improved customer value, and quick responses to customer requests (Narver et al. 2004; Menor and Roth 2007) (ITP1 to ITP3 in Appendix A). The independent variables included three factors. Strategic alignment is measured by five items (STA1 to STA5 in Appendix A) so as to capture the extent of service goals that are fulfilled by the underlying customer service system (Narver et al., 2004; Menor and Roth, 2007). We use four items to measure operational alignment
(OPA1 to OPA4 in Appendix A) in an attempt to understand the process and information needs that are met by the customer service system (Weill et al., 2002; Bieberstein et al., 2005; Gosain et al., 2005). We measure social alignment by looking at whether the company has established the service climate in its IT and business units (SOA1 to SOA6 in Appendix A) (Schneider et al., 1998; Reich \& Benbasat, 2000; Ray et al., 2004). The moderating variable is service integration level. Developed using the IBM SIMM, four levels of service integration for customer service systems are proposed: data integration, application and functional integration, process integration, and eco-system integration (SI in Appendix A). Data integration level adopts SIMM's first level. Application and functional integration level contains SIMM's second and third level, because both levels in SIMM emphasize the integration of enterprise internal systems. Process integration includes the fourth and fifth levels of SIMM, because these two levels in SIMM start to consider the flow integration between enterprise internal and external systems. At last, eco-system integration represents the sixth and seventh levels of SIMM, emphasizing a dynamically reconfigurable software architecture. A detailed definition of each level is listed in Table 3. The operational definitions of the variables are summarized in Table 4. 


\begin{tabular}{|c|c|}
\hline Level & Description \\
\hline Data integration & $\begin{array}{l}\text { The organization owns a basic enterprise Web site for customers to send } \\
\text { comments and complaints. The Web site has an independent member system, } \\
\text { from which customers can browse the site to join members, subscribe to com- } \\
\text { pany e-papers, search for information about products and services, apply for } \\
\text { services, or leave comments. There is no direct connection between the Web } \\
\text { site's member system and the company's internal Customer Relationship } \\
\text { Management (CRM) system. The employees of the customer service depart- } \\
\text { ment have to manually move the data from the Web site's member system and } \\
\text { import the data into the CRM system to process the requests of the customers. }\end{array}$ \\
\hline $\begin{array}{l}\text { Application and } \\
\text { functional } \\
\text { integration }\end{array}$ & $\begin{array}{l}\text { The enterprise Web site has connections to the internal (e.g., CRM, Enterprise } \\
\text { Resource Planning (ERP)) and external (e.g., Supply Chain Management } \\
\text { (SCM)) systems of the organization. There are standardized formats of data } \\
\text { transmission (e.g., Extended Markup Language (XML)). The data transmission } \\
\text { can be scheduled as automatically executed tasks within a certain period by } \\
\text { batch, or be designed as synchronized tasks to import data synchronously into } \\
\text { other related systems within the organization and without manual intervention. } \\
\text { The automation is only applied to those data that interchange with no flows } \\
\text { (e.g., receive an order form or add a new member). The processes that require } \\
\text { flows or complicated logistics should rely on manual operations or other } \\
\text { processes. }\end{array}$ \\
\hline $\begin{array}{l}\text { Process } \\
\text { integration }\end{array}$ & $\begin{array}{l}\text { For the enterprise, the interaction between internal/external systems becomes } \\
\text { more automatic. This not only makes customers register for services online } \\
\text { and transfer data into the internal system automatically, but also deals with } \\
\text { various processes involving business knowledge (e.g., identify a form which } \\
\text { the departments belong to, understand how to deal with different situations). } \\
\text { For example, when a user makes an order, the system will activate the } \\
\text { processes to fulfill the order automatically; if the order involves the cooperation } \\
\text { of external factories and stores, the system will send the order information to } \\
\text { the best route planning process and guarantee fast fulfillment of the order. }\end{array}$ \\
\hline $\begin{array}{l}\text { Eco-system } \\
\text { integration }\end{array}$ & $\begin{array}{l}\text { Every service component is modularized and independent. To meet customer } \\
\text { needs, the system is able to combine different service components to form new } \\
\text { ones. For example, the customer service system can be divided into the follow- } \\
\text { ing service components: member service, order service, and distribution ser- } \\
\text { vice. Users can select the services needed and integrate the service into their } \\
\text { systems or processes. }\end{array}$ \\
\hline
\end{tabular}

Table 4 - Operational Definition of Variables

\begin{tabular}{|c|l|}
\hline Variable & \multicolumn{1}{c|}{ Operational Definition } \\
\hline Strategic alignment & $\begin{array}{l}\text { The degree to which the underlying customer service system can support cor- } \\
\text { porate service strategies. }\end{array}$ \\
\hline Operational alignment & $\begin{array}{l}\text { The degree to which the underlying customer service system can fulfill corpo- } \\
\text { rate information and process needs. }\end{array}$ \\
\hline Social alignment & $\begin{array}{l}\text { The degree to which a common service climate is shared between IT and } \\
\text { business units. }\end{array}$ \\
\hline $\begin{array}{c}\text { Performance of } \\
\text { service-oriented IT }\end{array}$ & $\begin{array}{l}\text { The degree to which the expected goals of the underlying customer service } \\
\text { system are accomplished in terms of customer satisfaction, customer value, } \\
\text { and quick response. }\end{array}$ \\
\hline $\begin{array}{c}\text { Service Integration } \\
\text { Level }\end{array}$ & $\begin{array}{l}\text { The level of service integration achieved by the undelying customer service } \\
\text { system. }\end{array}$ \\
\hline
\end{tabular}




\begin{tabular}{|c|c|c|c|c|}
\hline Factors & Items & Loadings & Reliability $^{1}(\alpha)^{2}$ & AVE \\
\hline \multirow{5}{*}{ Strategic alignment } & (STA1) & 0.804 & \multirow{5}{*}{$0.914(0.881)$} & \multirow{5}{*}{0.68} \\
\hline & (STA2)) & 0.864 & & \\
\hline & (STA3) & 0.823 & & \\
\hline & (STA4) & 0.841 & & \\
\hline & (STA5) & 0.787 & & \\
\hline \multirow{4}{*}{ Operational alignment } & (OPA1) & 0.884 & \multirow{4}{*}{$0.904(0.858)$} & \multirow{4}{*}{0.70} \\
\hline & (OPA2) & 0.848 & & \\
\hline & (OPA3) & 0.779 & & \\
\hline & (OPA4) & 0.836 & & \\
\hline \multirow{6}{*}{ Social alignment } & (SOA1) & 0.851 & \multirow{6}{*}{$0.926(0.902)$} & \multirow{6}{*}{0.68} \\
\hline & (SOA2) & 0.837 & & \\
\hline & (SOA3) & 0.838 & & \\
\hline & (SOA4) & 0.866 & & \\
\hline & (SOA5) & 0.777 & & \\
\hline & (SOA6) & 0.760 & & \\
\hline \multirow{3}{*}{$\begin{array}{l}\text { Performance of } \\
\text { service-oriented IT }\end{array}$} & (ITP1) & 0.831 & \multirow{3}{*}{$0.802(0.942)$} & \multirow{3}{*}{0.58} \\
\hline & (ITP2) & 0.863 & & \\
\hline & (ITP3) & 0.556 & & \\
\hline Service level & $(\mathrm{SI})$ & 1.000 & $1(\mathrm{n} / \mathrm{a})$ & 1.0 \\
\hline
\end{tabular}

\section{Model Analysis and Results}

\section{Measurement Model Analysis}

We used a Partial Least Squares (PLS) approach for the data analysis. We chose this approach because of its minimal demands on sample size and its residual distributions, as well as for its ability to model formative and reflective constructs (Chin, 1998). According to the criteria established by Jarvis, Mackenzie, and Podsakoff (2003), the performance of service-oriented IT is modeled as formative because the direction of causality is from indicators to constructs, and items within a construct are not necessarily interchangeable or co-variational. Three IT-business alignment factors were modeled as reflective because the opposite conditions applied. The following PLS procedures have been suggested for the evaluation of the measurement properties of the constructs (Gosain et al., 2005; Patnayakuni et al., 2006; Wang et al., 2006). The first stage focused on an examination of item reliability through assessment of the factor loading of each item. A loading of 0.707 and above was considered to be desirable, and a loading of 0.5 and below was dropped (Hulland, 1999). The results listed in Table 5 confirm that the loadings of all of the items were larger than 0.760 , except for ITP3. We chose to keep this item to preserve content validity (Bollen and Leenox, 1991).

We next assessed convergent and discriminant validity. Based on the suggestion of Fornell and Larcker (1981), convergent validity can be examined using Cronbach's alpha, the composite reliability, and the average variance extracted (AVE). The results of our findings suggest that the Cronbach's alpha and composite reliability of all the constructs are above 0.7, which meets Nunnally's (1978) guidelines. The AVE for the constructs is also over 0.5 , indicating high internal consistency (see Table 5). Discriminant validity has been measured by looking at cross-loadings and AVE. The correlation pattern listed in Table 6 demonstrates that each item's correlation with its own construct is greater than its correlation with other constructs. Table 7 also confirms that the square root of the AVE for the defined construct is greater than its correlations with other latent constructs. The evidence overall suggests that the constructs demonstrate good measurement properties.

Since the respondent providing the measure of the predictor and criterion variable is the same person, there is a potential for the 


\begin{tabular}{|c|c|c|c|c|}
\hline Table 6 - Factor Structure Matrix of Loadings and Cross-Loadings \\
\hline Scale Items & $\begin{array}{c}\text { Strategic Alignment } \\
\text { (STA) }\end{array}$ & $\begin{array}{c}\text { Operational } \\
\text { Alignment (OPA) }\end{array}$ & $\begin{array}{c}\text { Social Alignment } \\
\text { (SOA) }\end{array}$ & $\begin{array}{c}\text { Performance of Ser- } \\
\text { vice-oriented IT (ITP) }\end{array}$ \\
\hline STA1 & $\mathbf{0 . 8 0 4 5}$ & 0.6163 & 0.509 & 0.4952 \\
\hline STA2 & $\mathbf{0 . 8 6 4 5}$ & 0.6385 & 0.5147 & 0.5405 \\
\hline STA3 & $\mathbf{0 . 8 2 3 2}$ & 0.5352 & 0.5247 & 0.5615 \\
\hline STA4 & $\mathbf{0 . 8 4 1 2}$ & 0.4911 & 0.3851 & 0.6234 \\
\hline STA5 & $\mathbf{0 . 7 8 7 1}$ & 0.4671 & 0.3365 & 0.384 \\
\hline OPA1 & 0.6108 & $\mathbf{0 . 8 8 4 3}$ & 0.3427 & 0.4221 \\
\hline OPA2 & 0.4761 & $\mathbf{0 . 8 4 8 2}$ & 0.3111 & 0.4224 \\
\hline OPA3 & 0.5925 & $\mathbf{0 . 7 7 9}$ & 0.2981 & 0.3585 \\
\hline OPA4 & 0.5605 & $\mathbf{0 . 8 3 6 2}$ & 0.4104 & 0.3903 \\
\hline SOA1 & 0.4465 & 0.3248 & $\mathbf{0 . 8 5 1 3}$ & 0.3886 \\
\hline SOA2 & 0.2853 & 0.2309 & $\mathbf{0 . 8 3 7 6}$ & 0.3513 \\
\hline SOA3 & 0.3749 & 0.2394 & $\mathbf{0 . 8 3 7 8}$ & 0.4285 \\
\hline SOA4 & 0.4036 & 0.3164 & $\mathbf{0 . 8 6 5 6}$ & 0.5232 \\
\hline SOA5 & 0.64 & 0.4226 & $\mathbf{0 . 7 7 6 9}$ & 0.5449 \\
\hline SOA6 & 0.6043 & 0.4981 & $\mathbf{0 . 7 5 9 8}$ & 0.6097 \\
\hline ITP1 & 0.6768 & 0.5178 & 0.5866 & $\mathbf{0 . 8 3 1 5}$ \\
\hline ITP2 & 0.6562 & 0.5387 & 0.6374 & $\mathbf{0 . 8 6 2 9}$ \\
\hline ITP3 & 0.6116 & 0.5145 & 0.5724 & $\mathbf{0 . 5 5 6 3}$ \\
\hline
\end{tabular}

\begin{tabular}{|c|c|c|c|c|}
\hline Scale Items & $\begin{array}{c}\text { Strategic Alignment } \\
\text { (STA) }\end{array}$ & $\begin{array}{c}\text { Operational } \\
\text { Alignment (OPA) }\end{array}$ & $\begin{array}{l}\text { Social Alignment } \\
\text { (SOA) }\end{array}$ & $\begin{array}{l}\text { Performance of Ser- } \\
\text { vice-oriented IT (ITP) }\end{array}$ \\
\hline STA & 0.825 & & & \\
\hline OPA & 0.668 & 0.837 & & \\
\hline SOA & 0.552 & 0.407 & 0.825 & \\
\hline ITP & 0.634 & 0.476 & 0.573 & 0.762 \\
\hline
\end{tabular}

occurrence of common method variance problem (Podsakoff et al., 2003). Harmon's single-factor test has been suggested to control for this problem (Podsakoff and Organ, 1986). This test suggests that common method bias exists when a general construct accounts for the majority of the covariance among all factors. In this analysis, each principal factor explains roughly equal variance (range $=20-24 \%$ ), indicating that common method effects are not a likely contaminant of the results.

\section{Structure Model Analysis}

A bootstrapping approach is used with 500 samples created for estimating path coefficients and confidence intervals. We first calculate the R-square $\left(R^{2}\right)$ parameter for the basic model (Model 1), which includes the three alignment factors and the dependent variable. All of the path coefficients are found to be significant, thus suggesting support for $\mathrm{H} 1, \mathrm{H} 2$, and H3 (See Table 8: Model 1). Then we follow Chin et al.'s (2003) PLS productindicator approach to detect the moderating effects. We obtain the $R^{2}$ of the moderating effect models by including independent variables, moderators, interaction terms, and the dependent variable in the model. Then we compare the $R^{2}$ of the moderating effect models against the $R^{2}$ of Model 1 to derive the $\mathrm{f}^{2}$ statistics and the pseudo-F statistics ${ }^{1}$.

According to the typology of the moderating variables developed by Sharma et al. (1981), service integration level is the quasimoderator of service-oriented IT performance for strategic and operational alignment because it not only interacts with the predictor variables (both STA $x$ SI and OPA $\times$ SI are significant at the 0.05 level in Models 2 and 3 ), but also is a predictor variable itself ( $\mathrm{SI}$ is sig- 


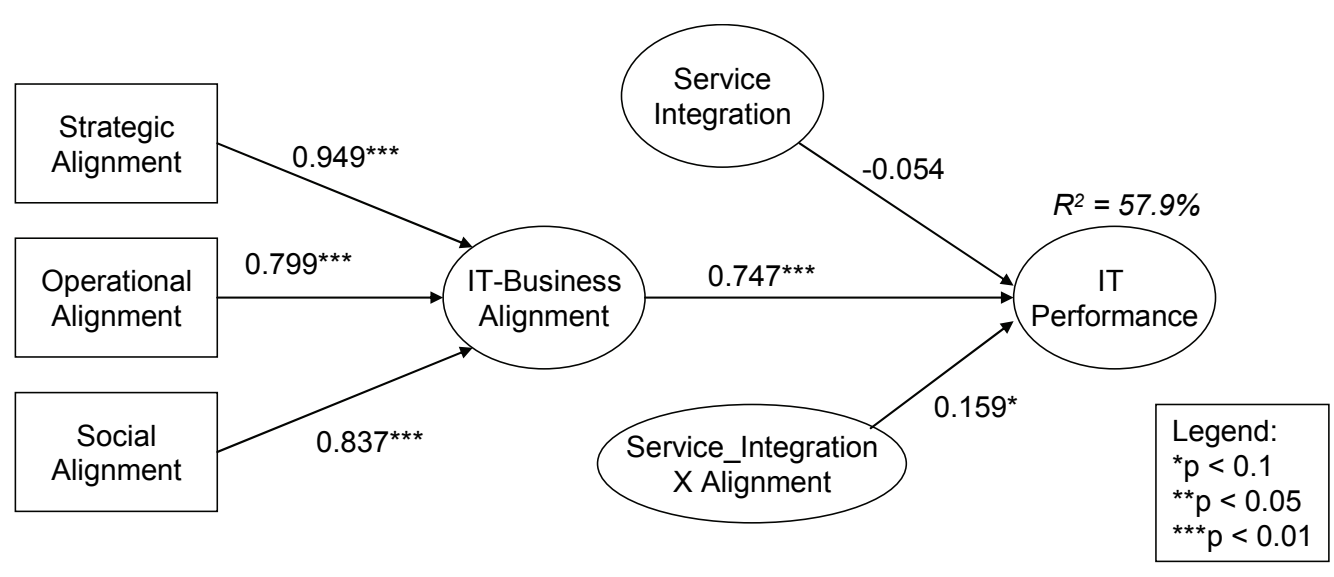

Figure 3 - Results of Path Analysis

\section{Table 8 - Testing of Hypotheses}

\begin{tabular}{|c|c|c|c|c|}
\hline & \multicolumn{4}{|c|}{ Dependent Variable: Performance of Service-Oriented IT } \\
\hline Independent Variables & Model 1 & Model 2 & Model 3 & Model 4 \\
\hline Strategic Alignment (STA) & $0.37(3.58)^{\star * *}$ & $0.41(3.89)^{* * *}$ & $0.39(3.57)^{\star * *}$ & $0.39(3.62)^{\star * *}$ \\
\hline Operational Alignment (OPA) & $0.11(1.74)^{\star *}$ & $0.14(1.67)^{\star *}$ & $0.17(2.18)^{\star \star *}$ & $0.14(1.76)^{\star *}$ \\
\hline Social Alignment (SOA) & $0.40(4.29)^{\star * \star}$ & $0.40(4.33)^{* * *}$ & $0.39(4.13)^{\star \star \star}$ & $0.42(4.20)^{\star * *}$ \\
\hline Service Integration (SI) & & $-0.09(-1.71)^{* *}$ & $-0.1(-1.65)^{* *}$ & $-0.08(-1.52)^{*}$ \\
\hline $\mathrm{STA} \times \mathrm{SI}$ & & $0.09(1.48)^{*}$ & & \\
\hline $\mathrm{OPA} \times \mathrm{SI}$ & & & $0.10(1.70)^{\star *}$ & \\
\hline $\mathrm{SOA} \times \mathrm{SI}$ & & & & $0.03(0.49)$ \\
\hline $\mathrm{R}^{2}$ & 0.613 & 0.639 & 0.639 & 0.632 \\
\hline Differenced $\mathrm{R}^{2}$ & & 0.026 & 0.026 & 0.019 \\
\hline$f^{2}$ & & 0.072 & 0.072 & 0.052 \\
\hline Pseudo F-value & & $7.2^{* * *}$ & $7.2^{\star \star \star}$ & $5.2^{* \star *}$ \\
\hline
\end{tabular}

nificant at the 0.1 level in Models 2 and 3 ). In Model 4, there is no interaction effect (SOA $x$ $\mathrm{SI}$ is not significant), but the service integration level is negatively associated with the criterion variable. Based on these facts, we suggest that the service integration level is not a moderator for social alignment but is one of the intervening, exogenous, antecedents, suppressors, or predictor variable types (Sharma et al., 1981). Therefore, the service integration level strongly moderates the performance of service-oriented IT for strategic and operational alignment, but not for social alignment, partially supporting $\mathrm{H} 4$.

To further investigate the relationships among these concepts, we treat IT-business alignment as a second-order construct consisting of the three first-order alignment constructs, and then test whether the moderating effect of service integration exists. Results of the analysis for the structural model are presented in Figure 3. We find that all specified paths between constructs in our research model have significant path coefficients. In terms of the moderating effect, the analysis reconfirms that service integration level is a moderator of firm performance (Alignment $\mathrm{SI}$ is significant at the 0.1 level).

\section{Discussion}

Although IT-business alignment has been one of the most significant challenges for IS practitioners over the last decade, relatively little research has been conducted about its 
Assessing IT-business alignment in service-oriented enterprises / Chang et al.

impacts in the SOE. In the previous section, we reported that IT-business alignment has a significant effect on the performance of service-oriented IT. We also found that, while service integration is a significant quasimoderator of the service-oriented IT performance for strategic and operational alignment, it does not exert a moderating effect for social alignment. We will discuss these facts in detail below.

\section{IT-Business Alignment in the SOE}

In our basic model (Model 1), $61.3 \%$ of the service-oriented IT performance was significantly explained by IT-business alignment in the SOE. Besides, the moderating effect models (Models 2, 3, and 4) with the interaction terms (service integration) significantly explained $63.9 \%, 63.9 \%$, and $63.2 \%$ of the performance variance, respectively. The literature finds support for the role of IT-business alignment in IT project success (e.g., Day, 1994; Rockart et al., 1996), and this research confirms that conclusion and further suggests that IT-business alignment has a significant effect in the context of the SOE. The result of this finding suggests that IT project managers must evaluate IT-business alignment and plan for the appropriate level of service integration before embarking on a serviceoriented IT project.

Besides, our framework provides criteria that address three important focus areas of ITbusiness alignment in SOEs. The first focus, "strategic alignment," calls for a customercentric IT planning strategy that can effectiely support the planning and development of new customer service tactics. The second focus, "operational alignment," requires a flexible IT infrastructure that enables seamless information sharing between IT and business units. The third focus, "social alignment," involves the development of a service climate throughout the enterprise. The results of our findings show that diagnosing the alignment using these three dimensions allows SOE managers to mitigate the project risk over the course of the implementation and assist in determining the appropriate levels of re- source allocation and management involvement.

\section{Service Integration Level}

This study has concluded that service integration level is a quasi-moderator of serviceoriented IT performance for strategic and operational alignment, but not for social alignment. We then testified whether the service integration is a mediator that underlies the relationship between social alignment and IT performance. The result shows that the mediating effect between social alignment and IT performance is not significant (the change in $R^{2}$ is negative); however, it can be an antecedent variable leading to social alignment (the change in $R^{2}$ is 0.624 , which is significant at the level of 0.01 ).

This result might be explained by users' absorptive capacity pertaining to knowledge creation and utilization (Zahra and George, 2002). While strategic alignment focuses on an overall customer-centric business visions, and operational alignment aims to promote flexible technology designs, social alignment requires intensive information sharing between IT and business units and the creatation of new knowledge about customers. Prior research has shown that modularity and standardization can efficiently and effectively reduce the structural and cognitive barriers that impede knowledge sharing (Malhotra et al., 2005). An enterprise with high service integration can efficiently break up complex processes into sub-processes that are performed independently by different enterprise units (Grant, 1996). Business units and IT units can focus on their sub-processes while maintaining an understanding of how these sub-processes connect with the overall enterprise process. Both units are better able to recognize what information they need to obtain from the other units, thereby reducing the amount of coordination communication and enabling richer information exchanges. Moreover, a high service integration level allows for real-time information exchanges and application integration (Gosain et al., 2003). It becomes easier for business units and IT units to generate new insights by integrating 
or synthesizing information. As a result, the service integration level acts as a contributor rather than a moderator of social alignment.

It is interesting to note that service integration level has a negative effect on performance in three models, which indicate that higher service integration will lead to lower perceived performance. This result might be explained by the fact that service-oriented IT is a relatively new technology with evolving standards and new software offerings. Prior research has shown that the implementation of service-oriented IT comprises of numerous technological and non-technological challenges (Chen and Vargo, 2010; Chang and Lue, 2009). We can expect that the difficulties in mitigating these challenges increase with the levels of service integration because more dispersed and heterogeneous systems are involved. If firms cannot find efficient ways to avoid these risks, the increased service level becomes a value barrier, not a contributor.

\section{Managerial Implications}

The results of the findings have two important implications for management. First, this study offers a useful framework for managers to assess IT-business alignment in the context of service orientation. The analysis identified the alignment as an important performance driver of service-oriented IT projects and includes three dimensions: strategic alignment, operational alignment, and social alignment. In an SOE environment where the differences of IT services and business services blur, managers have struggled for ways to explicitly manage IT capabilities to support business needs. The study shows that the IT capabilities must be managed to support customerpull strategy, modularized and standardized business processes, as well as service climate. These findings can serve as useful guidelines for SOE to ensure IT-business alignment.

Second, the higher the service integration level of the underlying service-oriented IT projects, the stronger IT-business alignment is required to ensure the project performance, as suggested by the empirical findings. At the higher levels of service integration, compa- nies not only consider integrating applications, but also engage in enterprise-wide business transformation, thereby requiring a tigher linkage between IT and business strategy. The result of our study also indicates that service integration level is an important moderator of service-oriented IT performance for strategic and operational alingment, but not for social alignment. It further suggests that service integration can be an antecedent variable leading to social alignment, because social alignment requires users' absorptive capacity which can hardly be achieved in low levels of service integration. Although this finding requires further examination, it indicates an integrated perspective to manage IT-business alignment for capturing the performance of service-oriented IT projects.

\section{Conclusion}

Increasing numbers of enterprises are transforming themselves into SOEs to retain their customers. They require a flexible and robust IT infrastructure to model, assemble, deploy, and manage business processes. However, how to implement these service-oriented IT successfully is still an unanswered question. While it is clear that IT-business alignment is a critical selection criterion for enterprise IT projects (Hong and Kim, 2002), we can expect a tighter link between IT-business alignment and the performance of service-oriented IT projects because these service-oriented IT projects require a higher level of business integration than do general IT projects. In this study, we propose a three-dimensional ITbusiness alignment framework in the SOE. The empirical results show that IT-business alignment is indeed critical in explaining the performance of service-oriented IT projects. In addition, we have found that the service integration level is a significant performance moderator for strategic and operational alignment and a significant contributor to social alignment. Therefore, for successful implementation of service-oriented IT, it is essential to determine the service integration level before ensuring that all underlying IT projects are strongly aligned with the business. 
Assessing IT-business alignment in service-oriented enterprises / Chang et al.

The contribution of this research is multifaceted. Enterprises at different levels of service integration can determine which and how much alignment should be targeted. The validated alignment measures can also help managers better gauge the shortcomings of existing customer service systems. Besides, IT researchers can build upon this model to further examine the factors that are discovered. This model also has limitations. Although we propose three business-IT alignment factors for the SOE, there may be other alignment categories that we have not included, such as structural alignment (Chan, 2002) and incentive alignment (Ba et al., 2001). In the future, we hope to extend our proposed framework to include other alignment factors, making this model a more general framework that can help managers apply measures to all kinds of systems or processes. Besides, to simplify the research design, we used IBM's service integration maturity model to measure the level of service integration in enterprise-based customer service systems. However, IBM's model is not necessarily accepted industry-wide. Furthermore, we make assumptions that enterprises are service-oriented if they invoke the concept of service integration. This assumption also needs to be verified in future work.

\section{Footnotes}

\footnotetext{
The formula for computing $\mathrm{f}^{2}$ statistics is $\left(\mathrm{R}^{2}\right.$ model $_{2,3}$, ${ }_{4}-R^{2}$ model $\left._{1}\right) /\left(1-R^{2}\right.$ model $\left._{2,3,4}\right)$. The pseudo $F$ statistics is computed by multiplying $f^{2}$ with $(n-k-1)$, where $n$ is the sample size and $\mathrm{k}$ is the number of independent variables in the basic model.
}

\section{Acknowledgements}

This article was based on a research project funded by Sayling Wen Cultural \& Educational Foundation and National Science Council, Taiwan. Part of this research was presented in Pacific-Asia Conference on Information Systems (PACIS), 2009. The authors wish to thank anonymous reviewers for their insightful comments on this article.

\section{References}

Avison, D., Jones, J., Powell, P., and Wilson, D. (2004), "Using and validating the strategic alignment model,“ Journal of Strategic Information Systems, 13, 223-246.

Ba, S., Stallaert, J., and Whinston, A. B. (2001), "Research commentary: Intorducing a third dimension in information systems design - The case for incentive alignment," MIS Quarterly, 12(3), 225-239.

Bieberstein, N., Bose, S., Walker, L., and Lynch, A. (2005), "Impact of serviceoriented architecture on enterprise systems, organizational structures, and individuals," IBM Systems Journal, 44(4), 691-708.

Bollen, K. and Leenox, R. (1991), "Conventional wisdom on measurement: $A$ structural equation perspective," Psychological Bulletin, 110(20), 305-314.

Broadbent, M. and Weill, P. (1997), "Management by maxim: How business and IT managers can create IT infrastructures," Sloan Management Review, 38(3), 77-92.

CFO Publishing Corporation. (2003), The new it value proposition: Focus on business process optimization, not cost cutting. Boston: MA.

Chan, Y. E. and Reich B. H. (2007), "IT alignment: what have we learned?" Journal of Information Technology, 22(4), 297-315.

Chan, Y. E., Sabherwal, R., and Thatcher, J. B. (2006), "Antecedents and outcomes of strategic IS alignment: An empirical investigation," IEEE Transactions on Engineering Management, 51(3), 27-47.

Chan, Y. E.(2002), "Why haven't we mastered alignment? The importance of the informal organization structure," MIS Quarterly Executive, 1(2), 97-112.

Chang, H., and Lue, C. (2009), "An exploratory study of risk factors for implementing service-oriented IS projects," Lec- 
ture Notes in Business Information Processing, 22, 83-95.

Chen, H. and Vargo, S. L. (2010). "Serviceoriented challenges for design science: Charting the "E"-volution," Pacific Asia Journal of the Association for Information Systems, 2(1), 1-15.

Cherbakov, L., Galambos, G., Harishankar, R., Kalyana, S., and Rackham, G. (2005), "Impact of service orientation at the business level," IBM Systems Journal, 44(4), 653-668.

Chin, W. W., and Barbara L. M.; Newsted, P.R. (2003), "A partial least squares latent variable modeling approach for measuring interaction effects: Results from a Monte Carlo simulation study and an electronic-mail emotion/adoption study," Information Systems Research, 14(2), 189-217.

Chin, W.W. (1998), "The partial least squares approach to structural equation modelling," Modern Methods for Business Research, Lawrence Erlbaum Associates, Inc., 295-336.

Chung, S. H., Rainer Jr., R. K., and Lewis, B. R. (2003), "The impact of information technology infrastructure flexibility on strategic alignment and application implementations," Communications of the Association for Information Systems, 11, 191-206.

Crawford, C. H., Bate, G. P., Cherbakov, L., Holley, K., and Tsocanos, C. (2005), "Toward an on demand serviceoriented architecture," IBM Systems Journal, 44(1), 81-107.

Day, G. S. (1994), "The capabilities of market-driven organizations," Journal of Marketing, 58(4), 37-52.

Fornell, C., and Larcker D. (1981), "Evaluating structural equation models with unobservable variables and measurement error," Journal of Marketing Research, 18(1), 39-50.
Gosain, S., Malhotra, A., and El Sawy, O. A. (2005), "Coordinating for flexibility in e-business supply chains," Journal of Management Information Systems 21(3), 7-46.

Grant, R. M. (1996), "Toward a knowledge based theory of the firm," Strategic Management Journal 17, Winter Special Issue, 109-122.

Hong, K. K. and Kim, Y. G. (2002), "The critical success factors for ERP implementation: an organizational fit perspective," 40, 25-40.

Hulland, J. (1999), "Use of partial least squares (PLS) in strategic management research: A review of four recent studies," Strategic Management Journal, 20(2), 195-204.

Huang, C. D., and Hu, Q. (2007), "Achieving IT-Business strategic alignment via enterprise-wide implementation of balanced scorecards," Information Systems Management, 24(2), 173-184.

IBM Global Service (2005), "Increase flexibility with the Service Integration Maturity Model (SIMM)" , (accessed June 16, 2008),

http://www.ibm.com/developerworks/ webservices/library/ws-soa-simm/

IBM Summit (2004), "Services Science: A New Academic Discipline? The Architecture of On Demand Business Summit Report," (accessed March 24, 2008),

http://domino.research.ibm.com/comm /www fs.nsf/images/fsr/\$FILE/summit report.pdf

Jarvis, C. B., Mackenzie, S. B., and Podsakoff, P. M. (2003), "A critical review of construct indicators and measurement model misspecification in marketing and consumer research," Journal of Consumer Research, 30(2), 199-218.

Khaiata M. and Zualkernan I. A. (2009), "A simple instrument to measure ITbusiness alignment maturity," Informa- 
Assessing IT-business alignment in service-oriented enterprises / Chang et al.

tion Systems Management, 26(2). 138-152.

Luftman, J. N., Papp, R. and Brier, T. (1999), "Enablers and inhibitors of businessIT alignment," Communications of the Association for Information Systems, 1(11), 1-25.

Luftman, J. (2000), "Assessing business-IT alignment maturity," Communications of the AIS, 4(14), 1-49.

Luftman, J. (2003), "Assessing IT/business alignment," Information Systems Management, 20(4), 9-15.

Malhotra, A., Gosain, S., and El Sawy, O. A. (2005), "Absorptive capacity configurations in supply chains: Gearing for partner-enabled market knowledge creation," MIS Quarterly, 29(1), 145187.

Menor, L. J., and Roth, A. V. (2007), "New service development competence in retail banking: Construct development and measurement validation," Journal of Operations Management, 25(4), 825-846.

Moody, K. W. (2003), "New meaning to IT alignment," Information Systems Management, 20(4), 30-35.

Narver, J. C., and Slater, S. F. (1990) "The Effect of a Market Orientation on Business Profitability," Journal of Marketing, 54(4), 20-35.

Narver, J. C., Slater, S. F., and MacLachlan, D. L. (2004), "Responsive and proactive market orientation and newproduct success," Journal of Product Innovation Management, 21(5), 334347.

Nunnally, J. C. (1978), Psychometric Theory, NY: McGraw-Hill.

Oh, W., and Pinsonneault, A. (2007), "On the assessment of the strategic value of information technologies: Conceptual and analytical approaches" MIS Quarterly, 31(2), 239-265.
Patnayakuni, R., Rai, A., and Seth, N. (2006), "Relational antecedents of information flow integration for supply chain coordination," Journal of Management Information Systems, 23(1), 13-49.

Petter, S., Straub, D., and Rai, A. (2007), "Specifying formative constructs in information systems research," MIS Quarterly, 31(4), 623-656.

Podsakoff, P. M. and Organ, D. W. (1986) "Self-reports in organizational research: Problems and prospects," Journal of Management, 12(4), 531544.

Podsakoff, P. M., MacKenzie, S. B., and Lee, J. (2003) "Common method biases in behavioral research: A critical review of the literature and recommended remedies," Journal of Applied Psychology, 88(5), 879-903.

Ray, G., Barney, J. B., and Muhanna, W. A. (2004), "Capabilities, business processes, and competitive advantage: Choosing the dependent variable in empirical tests of the resourcebased view," Strategic Management Journal, 25(1), 23-37.

Reich, B. H., and Benbasat, I. (2000), "Factors that influence the social dimension of alignment between business and information technology objectives," MIS Quarterly, 24(1), 81-113.

Rockart, J. F., Earl, M. J., and Ross, J. W. (1996), "Eight imperatives for the new IT organization," Sloan Management Review, 38(1), 43-55.

Schneider, B., White, S. S., and Paul, M. C. (1998), "Linking service climate and customer perceptions of service quality: Test of a causal model," Journal of Applied Psychology, 83(2), 150-163.

Shpilberg, D., Berez, S., Puryear, R., and Shah, S. (2007), "Avoiding the alignment trap in information technology," MIT Sloan Management Review, 5158. 
Slater, S. F., and Narver, J. C. (1999), "Research notes and communications: Market-oriented is more than being customer-led," Strategic Management Journal, 20(12), 1165-1168.

Slater, S. F. and Narver, J. C. (1998), "Customer-Led and Market-Oriented: Let's Not Confuse the. Two," Strategic Management Journal, 19, 1001-1006.

Sharma, S., Durand, R. M., and Gur-Arie, O. (1981), "Identification and analysis of moderator variables," Journal of Marketing Research, 18, 291-300.

Tallon, P. P., and Kraemer, K. L. (1999), "A process-oriented assessment of the alignment of information systems and business strategy: Implications for IT business value," For Submission to the Fourth Americas Conference on Information Systems (AIS), Maryland, USA, 1-10.

\section{About Authors}

Dr. Hsin-Lu Chang is an associate professor in the Department of Management Information Systems, National Chengchi University. She received a Ph.D. in information systems at the School of Commerce, University of IIlinois at Urbana-Champaign. Her research areas are in B2B e-commerce, IT value, technology adoption, and IT-enabled service innovation. She has published a number of papers on information systems and electronic commerce in journals such as Information Systems Journal, International Journal of Electronic Commerce, and Journal of Organizational Computing and Electronic Commerce.

Hsiang-En Hsiao received his M.S. in Management Information Systems at National Chengchi University, Taiwan. He is currently
Wang, E.T., Tai, J.C., and Wei, H. (2006), "A virtual integration theory of improved supply-chain performance," Journal of Management Information Systems, 23(2), 41-64.

Weill, P., Subramani, M., and Broadbent, M. (2002), "Building IT infrastructure for strategic agility," MIT Sloan Management Review, 44(1), 57-65.

Weiss, J. W., Thorogood, A., and Clark, K. D. (2006), "Three IT-business alignment profiles: Technical resource, business enabler, and strategic weapon," Communications of AIS, 2006(18), 676-691.

Zahra, S. A. and George, G. (2002), "Absorptive capacity: A review, reconceptualization, and extension," Academy of Management Review, 27(2), 185-203.

a Ph.D. student at National Chengchi University. He has presented and published his works in numerous international conferences. His research interests include serviceoriented architecture, enterprise systems, service sciences, and cloud computing.

Chia-Pei Lue received her M.S. in Management Information Systems at National Chengchi University, Taiwan. Her research interests include IT project risks and service sciences. For the past ten years, she has been working in IT department of international companies such as British American Tobacco Taiwan, Alexander Corporation, MiTAC-SYNNEX Group, and 2HD Studio. Her current position is application project manager in Carrefour Taiwan. 


\section{Appendix A - Survey Instrument}

Please choose the best description for your company's customer service system. (Note: the detailed description about each integration level has been provided in Table 3 in this study)

SI Service integration level

Level 1: Data integration

Level 2: Application and function integration

Level 3: Process integration

Level 4: Ecosystem integration

With regard to the customer service system referenced in the above question, please indicate your level of agreement with the following statements on the scale of 1 (strongly agree) to 7 (strongly disagree).

\section{[ Strategic alignment ]}

STA1 The system can effectively support the planning and development of the new customer service tactics.

STA2 The system can provide relevant information about a customer's preference for certain products.

STA3 Via the system, our enterprise has collected both marketing and competitor information continuously to improve customer services.

STA4 The design of system funcationalities is in accordance with the enterprise's broader goals.

STA5 The system can provide relevant information about customer satisfaction with the commodities or services that we offer.

\section{[ Operational alignment ]}

OPA1 The enterprise's customer service processes can be divided into clearly understood activities.

OPA2 Modulized method is adopted for the design of system functions.

OPA3 The system development follows a fixable and systematic procedure.

OPA4 In the face of changing customer's needs, the enterprise can adjust the system quickly to meet those needs.

\section{[ Social alignment ]}

SOA1 In our enterprise the IT executives and other departmental executives usually exchange their domain know-how to reduce information divides.

SOA2 Executives from each department will participate in planning for new information systems.

SOA3 There exist friendships between IT executives and executives from other departments.

SOA4 Our enterprise uses open channels of communication and the environment promotes teamwork.

SOA5 Customer service information is shared through well-developed channels in our enterprise.

SOA6 The executives in our enterprise have a basic knowledge of how to use IT to improve customer service.

\section{[Performance of service-oriented IT]}

ITP1 The system allows us to quickly respond to customers' demands.

ITP2 The system allows us to create greater value for customers.

ITP3 The system can effectively improve customer satisfaction. 